\title{
ASSESSING THE IMPACT OF CLIMATIC EVENTS ON HUMAN PRODUCTIVITY AND DEVELOPMENT IN THE NIGER DELTA REGION OF NIGRIA
}

\author{
Fred Igbo (Ph.D) $)^{\text {a }}$ Asor A.E. ${ }^{b}$ Joseph Upla (Ph.D) ${ }^{\mathfrak{c}}$ * \\ a fredigbo1@gmail.com \\ a \& b: Dept of Economics, Cross River State College of Education Akamkpa \\ c: Dept of Geography, Cross River State College of Education Akamkpa
}

\begin{abstract}
Climate change has become a global issue that world leaders are battling to keep in check. This work was carried out to examine the impact of climatic events on human productivity and development in the Niger Delta region of Nigeria. The area of study was in three Niger Delta states of Bayelsa, Rivers and AkwaIbom.The procedure for sampling was cluster sampling technique which involved demarcation of the states on ecological lines into north, central and south, two hundred and four respondents were used from each state making a sample size of six hundred and twelve to elicit the needed information. The research design was an explanatory field survey design aimed at gathering data from respondents using the questionnaire as the instrument. The technique employed for the data analysis was the chi square. The economic activity targeted was agriculture and the results from the study indicated that climatic events has altered the farming activities of the people. It was recommended that extension workers should be continuously trained and educated on current information about climate change and sent out to enlighten the farmers.
\end{abstract}

\section{Keyword: Niger Delta, Climate Change, Agriculture, coastlands}

\subsection{Introduction}

The Niger Delta is a geographical as well as a physiographic entity. Its geographical conception stems from the initial objectives of its demarcation primarily from the point of view of political partitioning of the country into six main geographical units. Physiographically, it is unique based on its location in the lower Niger valley with peculiar climatic variables.

On the whole, there is broad disparity in the ecological variables over the region. The true to type representation of the deltaic ecosystem coincides with the area around the coastal strip stretching from the warri area in the west though the coastal strip around Port Harcourt to Calabar in the Bight of Biafra around the Bakassi Peninsula. These areas experience the typical oceanic influence characterized by adequate yearly rainfall. Abundant rainfall produces incidents of flooding, water logging and acidification. Further on in the 
rain forest belt adequate receipt of rainfall favours the growth of equatorial rainforest vegetation with hdrophytic (water loving) plant adaptation.

The Guinea/derived Savanna in the hinterland comes under effect of aridity and sporadic incidence of rainfall. In all cases, human activity patterns significantly reflect the nature of ecosystemic peculiarities. Human productivity in this region as elsewhere, depends significantly on the weather regime or cycle. The pattern of weather control the available opportunities or constraints that enhance or retard the nature of development. In this envisaged research endeavor, our focus is on identification and characterization of the specific weather incidents in the different ecological domains in the Niger Delta region and equally attempt explanations of their causation in a bid to proffering solution to them.

\subsection{Statement of the problem}

The recognition given to the importance of climatic events in human activity dates back to antiquity and still continues to assume large scale prominence in our today's world. In the developed world regions daily activities and overall programmes are planned with a clear view of daily weather regimes, the nature of the specific environmental situations and inherent implications of development of projects in hazard prone zones. In relation to daily weather regimes, daily weather forecasts provides information on specific cycles of weather for activities to be carried out. In temperate world and further on in the polar/tundra regions strict warnings are provided to households and the general society on possible onslaught of snowfall which might be deleterious to automobile users and other outdoor activities that pertains to peak period of winter in the areas affected.

In case of development of major projects, Environmental Impact Assessment (EIA) is carried out to ascertain the ecological or social impact of the location of such a project in the area. Fundamentally, the social implication is most paramount where activities are located in hazard/risk prone zones such as areas liable to flooding, earthquake, volcano belts gully prone/landslide belts and so on.

In the Niger Delta and most parts of Nigeria, little consideration is given to these facts. On daily and recurrent basis; farmers, commercial business men, fisher men, school children, civil servants, construction workers and a host of others face grueling incidents of weather events such as stormy weather, abrupt flooding of sites, excessive insolation and so on due to lack of information on daily cycles of weather events. Lives have been lost, properties destroyed, man hours lost and many other unsavory experiences caused by neglect of appreciation of weather events.

Accordingly, flood incidents, windstorm effects, collapsed building and accidents on fishing grounds in the lagoons and high seas in the process of fishing expedition by fisher men have been reported. Further into the hinterland the savanna regions, grievous or devastating bouts of harmattan wind may result in devastating incidence of bush fire that do gulp farm lands, gut residential buildings and other valuable properties. This proposed research is therefore focused on identification of prevalence of environmental incidence of weather events and their corresponding weather precursors in a bid to suggesting likely measures of mitigations or adaptation by affected persons.

\subsection{Research objectives}

The research is guided by the following specific objectives

- To investigate the overall impact of climate events on human productivity in Niger Delta Region

- To investigate the spatial variations in the impact of climate events over the regions

\subsection{Research hypothesis}

In line with the research objectives, two research hypothesis have been formulated to guide the research as follows:

\section{Hypothesis 1}

Ho: There is no significant impact of climate events on human productivity in the Niger Delta region

H1: There is a significant impact of climate events on human productivity in the Niger Delta region 


\section{Hypothesis II}

Ho: Impact of climatic events do not vary spatially over the region

H1: Impact of climatic events vary spatially over the region.

\section{Literature review}

\subsection{Concept of Climate Change}

Climate is the weather condition of an area over a number of years (Mama \&Osinem, 2007). It is the regular pattern of weather conditions of a particular place. The Intergovernmental Panel on Climate Change (IPCC, 2007) glossary definition shows that:

Climate is the average weather within a given duration. It is the statistical description in terms of the mean and variability of relevant quantities over a period of time ranging from months to thousands or millions of years. The classical period is usually 30 years and the quantities are most often surface variables such as temperature, precipitation and wind.

Climate is the typical weather conditions experienced at any location or area over series of years. Weather conditions such as rainfall, sun intensity, surface temperature and other meteorological elements recorded on interval for years and the average taken at the end of the targeted period is referred to as the climate of the location where such data were collected.

All human endeavours depend on the weather system. This underscores the need for reliance on the daily weather forecast in every activity planned for the day. Adams (1995) elaborated on the essence of weather events/climatic regimes in our daily lives by reference to the essence of local as vital decisive factor in activity planning. According,

A good understanding of the weather and climatic patterns are vital elements in agricultural systems planning or evaluation of other economic strategies (Means 2008). The Niger Delta region comprises two broad ecological zones of distinct climatic regimes - the sub-quatorial per humid south and the Guinea Savanna tropical continental North (Papadaski 2010). These broad ecological biomass have serious implications for human productivity and activity scales. The current climate change phenomenon has contributed to the worsening ecological crisis in the region. Further down in the coastal fringes increased sea level rise has caused incursion of the sea into the coastlands. This means a corresponding intrusion of salt water into fresh water, invasion and destruction of mangrove ecosystem, coastal wetlands and coastal beaches. Coastal inundations and erosion with their associated settlement disruption are currently reported of Nembe in Eket and other coastal settlements in Bayelsa, Delta, Cross River, Rivers and other coastal locations in Nigeria (Odjugo, Akpodiogaga and Wiroye, 2010)

The Nigerian Meteorological Agency (NIMET) in its 2012 climate review provided a glaring picture of the climate/weather trends in the current climatic change scenario in Nigeria. The report focused on sectorial impact of climate and aspects of the result read thus:

- In one of the synopsis of the flood impact on Agriculture, it was indicated that out of the major food crops (yam, cassava, maize, sorghum, rice) being produced in the country, yam would be the most affected followed by rice and cassava

- Farming in three communities in Oshimili South and Ndokwa East Local Government Areas of Delta State were destroyed by flood waters and over 350 hectares of cassava farmlands were washed away in Edo State by the flood

- Primary health facilities in several states were flooded thereby limiting access to health facilities and basic health services especially in Bayelsa and Delta States.

- Other prevalent health problems reported include diarrhoea, malaria and typhoid particularly in the coastal states of Delta, Rivers Bayelsa, etc. 
Beside these excerpts of reports on two sectors, agriculture and health; similar reports were provided in other sectors of the economy including education. It stated inter alia: "Reports also have it that the Niger Delta University (NDU) Amassoma in Bayelsa state was also submerged by flood".

The NIMET review also highlighted certain features of our weather systems which are precarious to our economic productivity in Nigeria and the Niger Delta in particular. Some striking examples relate to anomalies certain elements of weather and climate namely rainfall, temperature and wind. Temperature anomaly for the year 2012 recorded for Calabar, Uyo, Eket with maximum values lower than normal by $0.5-$ 2.5 degrees Celcius. This condition discourages condensation and escalates temperature invasion which instigates drought and aridity.

The heavy torrential rainfall experienced over much of the region has significant negative impact on the impact terrain or landforms morphology (Ofama, 1995). Important features of the landscape impact include gully erosion, sheet erosion, soil acidification and landslide activities (Eze, 2011). Over much of the region significant incidence of gully are present in such areas as Calabar, Uyo, Port Harcourt, Delta and Bayelsa States. Soil acidification or leaching presents a formidable challenge to agricultural productivity. Frequent incidents of failed culverts and surface water logging are also serious menace to transportation and mobility. These among other challenges informed the objective of this envisaged research.

\subsection{Agricultural Production in Niger Delta Region of Nigeria}

Although climate change is an inherently global issue, the impacts will not be felt equally across the planet. Developed and developing countries alike, are all experiencing the impact of climate change. The Niger Delta region found in a developing country like Nigeria is experiencing serious impacts of climate change on agriculture in the region. As with most parts of Nigeria, agriculture is the dominant aspect of the rural economy as farming assumes considerable importance in Niger Delta. The region has been described as the richest wetland in Africa and the home of numerous species of aquatic and terrestrial plants and animals. When climatic patterns shift, the spatial distribution of croplands, animals' habitats and fish populations soon follows, significantly impacting agriculture and food production (Ariel \& Robert, 2011). Before the recent climate change in the Niger Delta, the people engaged on utilization of the surplus natural resources from their environment to make ends meet. They made their living from the exploitation of the resources of their land, water and forest as animal and crop farmers, fishermen and hunters. The economic activities of the people were soon distorted as a result of the environmental degradation caused by climate change and exploration and exploitation activities of multinational oil companies (Akinro, Opeyemi\&Ologunagba, 2008). The Niger Delta is highly susceptible to adverse environmental changes occasioned by climate variation because it is located in the coastal region of the world where the effects are more felt (Uyigue\&Agho, 2007). Climate change has been noted to affect the rearing of animals, cultivation of crops, fish farming and fishing activities as well as the farming families in all the regions of the world including the Niger Delta.

\subsection{Empirical review}

A study carried out by Thaddeus, Chukwudumebi, Nnaemeka and Victoria (2011) on climate change awareness and adaptation in the Niger Delta region of Nigeria adopted the survey research design and was guided by 4 research questions and 2 hypotheses. The population comprised of farmers estimated to be $7,814,858$. Multistage (random) sampling technique was used. Three states - Cross Rivers, Delta and Rivers were randomly selected from the nine Niger Delta states for the study. A total of 400 farmers constituted the sample size for the study while questionnaire and interview schedule were used to collect data. Percentage, mean score, standard deviation and factor analysis with varimax rotation were used in data analysis, the results were presented as tables, figures and charts. Findings of the study revealed that institutional problems, government failures and resistance to change are the major constraints to adaptation strategies. Results of the study further revealed that $(81.0 \%)$ of the total number of respondents in the study did not know of the existence of a bill on climate change in the National Assembly. The study recommended that closer 
interaction of the lawmakers with their constituents such as engaging in Town Hall Meetings and regular communication of activities of the Climate Change Committees in the Senate and House of Representatives. Furthermore, the Nigerian legislature should make deliberate efforts at sensitizing the Nigerian public of activities of its Committees on Climate Change. This study, like the current study, focuses on climate change and agricultural production but differs as emphasis is placed only on awareness and adaptation policies.

Another study conducted by Joshua, Ajiboye, and Rashid (2011) on impacts of climate change on rice production in Nigeria adopted the survey research design. The survey covered 20 states in Nigeria, which were selected to represent the major rice producing states in the country, namely: Adamawa, Anambra, Benue, Borno, Cross River, Ebonyi, Edo, Ekiti, Jigawa, Kaduna, Kano, Kebbi, Kogi, Kwara, Niger, Ondo, Ogun, TarabaYobe and Zamfara states. Six (6) research questions guided the study. The population for the study comprised of all rice farmers in the county. A sample of 60 rice farmers was randomly selected from each state, making a total of 1200 respondents. Data were collected with the use of structured questionnaire administered on the sampled rice farmers. The study employed the Ricardian approach to test the relative importance of climate normal (average long-term temperature andprecipitation) in explaining net revenue from Nigerian rice production under irrigation and dry land conditions and used descriptive statistics to answer research questions. Results from the study showed that increase in temperature and decreased precipitation will reduce net revenue for dry land rice farms but increase revenue for irrigated farms. The study recommended the use of irrigation on dried regions or during drought in the coastal regions. This study is similar to the current study as both investigates the impact of rising temperature and precipitation brought about by climate change but differs in the limitation of the study to only rice production.

\subsection{Methodology}

The study was carried in three Niger Delta states: Bayelsa, Rivers and Akwaibom states. The population consists of residents of these Niger Delta states engaged in economic activities, specifically farming. The procedure for sampling was cluster sampling technique which involved demarcation of the states on ecological lines into north, central and south, two hundred and four respondents were used from each state making a sample size of six hundred to elicit the needed information. The research design was an explanatory field survey design aimed at gathering data from respondents using the questionnaire as the instrument. The technique employed for the data analysis was the chi square.

For the purpose of this work the analysis was carried out using only the first hypothesis state as thus:

Ho: There is no significant impact of climate events on human productivity in the Niger Delta region

H1: There is a significant impact of climate events on human productivity in the Niger Delta region

Table 1

Responses from farmers on the impact of climate events on Agricultural activities

\begin{tabular}{|l|l|l|l|l|l|}
\hline & A & SA & D & SD & Total \\
\hline Obs & 154 & 34 & 10 & 6 & 204 \\
\hline Exp & 145 & 34.67 & $15 ; 33$ & 9 & \\
\hline Obs & 154 & 20 & 18 & 12 & 204 \\
\hline Exp & 145 & 34.67 & 15.33 & 9 & \\
\hline Obs & 127 & 50 & 18 & 9 & 204 \\
\hline Exp & 145 & 34.67 & 15.33 & 9 & 612 \\
\hline Total & 435 & 104 & 46 & 27 & \\
\hline
\end{tabular}


Table 2

Chi squared analysis from respondents

\begin{tabular}{|l|l|l|l|l|l|}
\hline Cells & Fo & Fe & Fo - Fe & $(\text { Fo }- \text { Fe })^{\mathbf{2}}$ & $(\mathbf{F o}-\mathbf{F e})^{\mathbf{2}} / \mathbf{F e}$ \\
\hline A & 154 & 145 & 09 & 81 & 0.56 \\
\hline B & 34 & 34.67 & -0.67 & 0.45 & 0.01 \\
\hline C & 10 & 15.33 & -5.33 & 28.41 & 1.86 \\
\hline D & 06 & 09 & -3 & 09 & 01 \\
\hline E & 154 & 145 & 09 & 81 & 0.56 \\
\hline F & 20 & 34.67 & -14.67 & 215.21 & 6.21 \\
\hline G & 18 & 15.33 & 2.67 & 7.13 & 0.47 \\
\hline H & 12 & 09 & 3 & 09 & 01 \\
\hline I & 127 & 145 & -18 & 324 & 2.23 \\
\hline J & 50 & 34.67 & 15.33 & 235.01 & 6.78 \\
\hline K & 18 & 15.33 & 2.67 & 7.13 & 0.47 \\
\hline L & 09 & 09 & 0 & 0 & 0 \\
\hline
\end{tabular}

Calculated value $\mathrm{X}^{2}=21.25$

df at.05 level of significance 12.59 (tabulated/critical)

decision rule: since X2 calculated of 21.5 is greater than the critical value of $X 2=12.59$, we reject the null hypotheses and accept the alternate hypothesis.

Discussion of findings

Indications from the study revealed that rainfall pattern has changed,there is also increased cost of production and resulted to poor quality andquantity of produce. The farmers indicated that climate change has impacted highly on clearing of farmland, rainfall pattern and flooding of farmland.

Climate change has caused moderate but negative impact on crop production in the region. Though the perceived impact of climate change on crop production in the region is moderate, not high as purported, these findings are in agreement with reviewed literature indicating that average weather variation has caused a drastic negative change to crop production (Molua\&Lambi, 2006; Christensen \&Lettenmaier, 2007; Alcamo, Moreno, Nováky, Bindi, Corobov, Devoy\&Shvidenko, 2007; Schlenker\& Roberts, 2009; Idowu, Ayoola, Opele\&Ikenweiwe, 2011).

\section{Implications of the study}

The results of this study have provided empirical evidence of the impacts of climate change in the Niger Delta region of Nigeria to be moderate. This will provide guide to the government and relevant authorities on the extent of help and information to be giving to the farmers to encourage production in the region. Most of the farmers reported that poverty level is on the rise. This is good information to government for re-assessing the poverty level in the country and providing current index.

\section{Recommendations}

Based on the findings of this study, the following recommendations have been proffered:

- Extension workers should be continuously trained and educated on current information about climate change and sent out to enlighten the farmers. This will enable them to update and synchronize ideas with the farmers.

- Farmers in the region should be encouraged by providing incentives and subsidizing inputs for them. This will go a long way in improving production especially as most farmers agree to continue cultivation even with the observed changes

- Most crop farmers in the region practice rain-fed agriculture. With the altered rainfall pattern the farmers are unable to effectively predict the trend. Thus it is necessary for the government and other relevant 
authorities to constantly provide information on rainfall distribution ahead of time to help the farmers plan.

- Fish farmers should be trained by government and well-meaning local and international organizations on recent fish keeping practices suitable in this era of climate change. Fishermen should be provided with standard fishing gears especially motorized canoes and boats to enable them travel less tediously to the long distance in search of the displaced (school of) fishes for a good catch and as well a means of encouraging continue fishing in the region to reduce hardship.

- Farmers, especially the animal farmers should be encouraged to use improved breeds/species. It is observed that the farmers still rear the same species and types of animal without consideration of change. This has a bad impact on the growth of the sector in the region as species' range is changing due to average weather variation. 


\section{References}

Abisola, A. 2013. Where cultivation meets conflict: Farming in the Niger Delta. Nourishing the planet. Retrieved April 17, 2013, from http://blogs.worldwatch.org/nourishingtheplanet/where-cultivationmeetsconflict-farming-in-the-niger-delta/

Adesiji, G. B., Baba, S. T. \&Tyabo, I. S. 2011. Effects of climate change onpoultry production in Ondo state, Nigeria. Russian Journal ofAgricultural and Socio-Economic Sciences, 2(14), 55-60.

Agwu E. A. 2006. Status of fish farming in Isoko area of Niger Delta Nigeria; implications for extension and global approaches to extension practices. Journal of agricultural extension, 2(2), 0794-1005.

Ahaoma, K. 2012, November 7. End of the road: a special report on the Nigeria flood disaster. National Daily.

Akinro, A. O., Opeyemi, D. A., \&Ologunagba, I. B. 2008. Climate change and environmental degradation in the Niger Delta area of Nigeria: Its vulnerability, impacts and possible mitigations. Research Journal of Applied Sciences, 3(3), 167-173.

Alcamo, J., Moreno, J. M., Nováky, B., Bindi, M., Corobov, R., Devoy, J. N \&Shvidenko A. 2007. Impacts, Adaptation and Vulnerability in Europe. In Climate Change: Fourth Assessment Report of the Intergovernmental Panel on Climate Change. Cambridge, United Kingdom. Cambridge University Press.

Aletan, A., Martins, O., \&Idowu, O. A., 2001. Mitigating the effects of floods and erosion in the Niger south catchment area through integrated flood management (IFM). Environmental Management Conference, Federal University of Agriculture Abeokuta, Nigeria. University Press.

Allison, E. 2009. The Copenhagen Diagnosis: Updating the World on the Latest Climate Science. UNSW Climate Change Research Center. Sydney, Australia.

Amanda, B. 2013. The causes, history and effects of acid rain. Retrieved April 7, 2013, from http://geography.about.com/od/globalproblemsandissues /a/acidrain.htm

Aweto, A. O., 2011. Agriculture in Urhoboland. Retrieved April 7, 2013, from http://www.waado.org/geography/Agriculture/Agruclture-Aweto.html

Awosika, L. F. 1995. Impacts of global climate change and sea level rise on coastal resources and energy development in Nigeria. In: Umolu, J. C. (ed). GlobalClimate Change: Impact on Energy Development. Nigeria: Damtech Press.

Bhusal, Y. R. 2009. Local peoples' perceptions on climate change, its impacts and adaptation measures in Mid-Mountain Area of Nepal (A case studyfromKaski District).Unpublished. Forestry Research Thesis Submitted to Tribhubhan University, Institute of Forestry, Pokhara, Nepal.

Intergovernmental Panel on Climate Change. 2011. Climate issues in the $21^{\text {st }}$ century. Retrieved December 28, 2012, from

Mama, R. O., \&Osinem E. C. 2007. Ecological features of tropical forests and environment forestry. Nsukka, Nigeria: Great AP Express Publishers.

Oladipo, E. O. 1995. An indication of abrupt change of rainfall and it potentialimpact on energy development in Nigeria. In: Umolu, J. C. (ed). Global Climate Change: Impact on Energy Development. Nigeria: Damtech Press. 